\title{
Effect of cooling heat-stressed dairy cows during the dry period on insulin response
}

\author{
S. Tao, ${ }^{*}$ I. M. Thompson, ${ }^{*}$ A. P. A. Monteiro, ${ }^{\star}$ M. J. Hayen, ${ }^{\star}$ L. J. Young, $†$ and G. E. Dahl ${ }^{\star 1}$ \\ *Department of Animal Sciences, and \\ †Department of Statistics, Institute of Food \& Agricultural Sciences, University of Florida, Gainesville 32611
}

\begin{abstract}
Heat stress (HT) during the dry period affects hepatic gene expression and adipose tissue mobilization during the transition period. In addition, it is postulated that HT may alter insulin action on peripheral tissues. Our objective was to evaluate the effect of cooling heatstressed cows during the dry period on insulin effects on peripheral tissues during the transition period. Cows were dried off $46 \mathrm{~d}$ before expected calving and assigned to 1 of 2 treatments: HT $(\mathrm{n}=16)$ or cooling $(\mathrm{CL}, \mathrm{n}=$ 16). During the dry period, the average temperaturehumidity index was 78 , but CL cows were cooled with sprinklers and fans, whereas HT cows were not. After calving, all cows were housed and managed under the same conditions. Rectal temperatures were measured twice daily (0730 and $1430 \mathrm{~h}$ ) and respiration rate recorded 3 times weekly during the dry period. Dry matter intake was recorded daily from dry-off to $42 \mathrm{~d}$ relative to calving (DRC). Body weight and body condition score were measured weekly from dry-off to 42 DRC. Milk yield and composition were recorded daily to $42 \mathrm{wk}$ postpartum. Glucose tolerance tests (GTT) and insulin challenges (IC) were performed at dry-off, $-14,7$, and $28 \mathrm{DRC}$ in a subset of cows $(\mathrm{HT}, \mathrm{n}=8$; $\mathrm{CL}, \mathrm{n}=8)$. Relative to HT, CL cows had lower rectal temperatures $\left(39.3\right.$ vs. $\left.39.0^{\circ} \mathrm{C}\right)$ in the afternoon and respiration rate (69 vs. 48 breath/min). Cows from the cooling treatment tended to consume more feed than HT cows prepartum and postpartum. Compared with HT, CL cows gained more weight before calving but lost more weight and body condition in early lactation. Cows from the cooling treatment produced more milk than HT cows (34.0 vs. $27.7 \mathrm{~kg} / \mathrm{d})$, but treatments did not affect milk composition. Treatments did not affect circulating insulin and metabolites prepartum, but CL cows had decreased glucose, increased nonesterified fatty acid, and tended to have lower insulin concentrations in plasma postpartum compared with HT cows.
\end{abstract}

\footnotetext{
Received February 1, 2012.

Accepted May 7, 2012.

${ }^{1}$ Corresponding author: gdahl@ufl.edu
}

Cooling prepartum HT cows did not affect the insulin responses to GTT and IC during the transition period and glucose responses to GTT and IC at -14 and 28 DRC were not affected by treatments. At 7 DRC, CL cows tended to have slower glucose clearance to GTT and weaker glucose response to IC relative to HT cows. Cows from the cooling treatment had stronger nonesterified fatty acid responses to IC postpartum but not prepartum compared with HT. In conclusion, cooling heat-stressed dairy cows in the dry period reduced insulin effects on peripheral tissues in early lactation but not in the dry period.

Key words: heat stress, dry period, insulin response, dairy cow

\section{INTRODUCTION}

One of the consequences of exposure to environmental heat stress is a reduction in milk yield. Heat stress compromises lactational performance not only when occurring during lactation (Collier et al., 2006) but also during the nonlactating period before parturition. In particular, exposure to heat stress during the dry period impairs mammary gland development (Tao et al., 2011), which in turn, decreases milk yield in the subsequent lactation (Wolfenson et al., 1988).

In addition to a decrease in DMI, heat stress alters the metabolism of lactating dairy cows. Heat-stressed cows in midlactation have faster glucose clearance and increased insulin response to a glucose tolerance test (GTT) compared with pair-fed contemporaries under thermoneutral conditions, which indicates that heat-stressed midlactation cows have more sensitive insulin responses at peripheral tissues (Wheelock et al., 2010). Further, the ability to mobilize adipose tissue is also compromised by heat stress during midlactation (Wheelock et al., 2010). Even though the physiological mechanisms are unclear, it is believed that these metabolic modifications under heat stress during midlactation account for approximately 50\% of the milk production loss observed (Rhoads et al., 2009; Wheelock et al., 2010), whereas decreased DMI explains the remainder of the depressed milk yield. However, it is 
unknown if the responses of peripheral tissues to heat stress are similar during early and late lactation to those observed in midlactation.

During the dry period, cooled cows have increased DMI compared with heat-stressed cows (Tao et al., 2011). Relative to heat-stressed cows, those under cooling during the dry period have higher circulating NEFA in early lactation (do Amaral et al., 2009). Corresponding to the higher adipose tissue mobilization, cooled cows have higher hepatic FA uptake and incorporate more preformed FA into milk fat in early lactation compared with noncooled herdmates (do Amaral et al., 2009). However, the effect of cooling heat-stressed dry cows on the effect of insulin at peripheral tissues during the transition period has never been evaluated. It was hypothesized that cooling heat-stressed dairy cows during the prepartum period decreased the insulin responsiveness of peripheral tissues during the transition period. Thus, the objective of the current study was to study the effect of cooling heat-stressed dairy cows during the dry period on the insulin response at peripheral tissues during late gestation and early lactation.

\section{MATERIALS AND METHODS}

\section{Animals, Experimental Design, and Sampling}

The experiment was conducted at the University of Florida Dairy Unit between June and November 2010. The Institutional Animal Care and Use Committee of the University of Florida approved all of the experimental procedures. Approximately $46 \mathrm{~d}$ before expected calving, 32 multiparous Holstein cows were dried off and randomly assigned to 1 of 2 treatments: heat stress $(\mathbf{H T}, \mathrm{n}=16)$ or cooling $(\mathbf{C L}, \mathrm{n}=16)$, based on mature equivalent milk production (HT: $12,045 \mathrm{~kg}$; CL: 12,100 $\mathrm{kg}$ ) of the just completed lactation. The average parity (means \pm SEM) of HT and CL cows was $1.4 \pm 0.2$ and $1.7 \pm 0.2$, respectively and did not differ between treatments $(P=0.68)$. All of the calving events occurred from July to September and were evenly distributed among treatments.

Cows were housed in a freestall barn during the dry period with a cooling system in the stall area for CL cows consisting of shade, sprinklers (Terregena Inc., Raleigh, NC), and fans (J\&D Manufacturing, Eau Claire, WI), whereas only shade was provided for HT cows. Sprinklers turned on automatically for $1.5 \mathrm{~min}$ at 6-min intervals when ambient temperature exceeded $23.9^{\circ} \mathrm{C}$ and fans ran continuously. Photoperiod $(14 \mathrm{~h}$ light and $10 \mathrm{~h}$ dark) in the dry cow barn was provided by metal halide lights to approximately 600-lx intensity at eye level of the cows. The lights were kept on from 0600 to 2000 h. After calving, lactating cows from both treatments were housed in the same freestall barn with sprinklers and fans and managed as a single group.

Air temperature and relative humidity were measured using Hobo Pro Series Temp probes (Onset Computer Corp., Pocasset, MA) every $30 \mathrm{~min}$. The temperature-humidity index was calculated based on following equation: temperature-humidity index $=(1.8$ $\times \mathrm{T}+32)-[(0.55-0.0055 \times \mathrm{RH}) \times(1.8 \times \mathrm{T}-26)]$, where $\mathrm{T}=$ air temperature $\left({ }^{\circ} \mathrm{C}\right)$ and $\mathrm{RH}=$ relative humidity (\%) (Dikmen et al., 2008). Rectal temperature was measured using a GLA M700 digital thermometer (GLA Agricultural Electronics, San Luis Obispo, CA) twice daily (0730 and $1430 \mathrm{~h}$ ) and respiratory rate was counted 3 times weekly (1500 h, Monday, Wednesday, and Friday) during the prepartum period. During the dry period and the first $6 \mathrm{wk}$ postpartum, BW was recorded and BCS was scored for each cow once weekly. Additionally, starting at $7 \mathrm{wk}$ postpartum, daily BW was recorded by the AfiFarm system (S.A.E. Afikim, Kibbutz Afikim, Israel) at each milking until 42 wk postpartum. Lactating cows were milked twice daily (0800 and $2000 \mathrm{~h}$ ) and daily milk production was recorded up to 42 wk postpartum. Milk composition was measured by the AfiLab milk analyzer (S.A.E. Afikim) at each milking until 42 wk postpartum. Dry cows were fed once per day $(0800 \mathrm{~h})$ and lactating cows were fed twice daily (0730 and $1300 \mathrm{~h}$ ). Daily DMI was measured from dry-off until $42 \mathrm{~d}$ relative to calving. The composition of diets for dry and milking cows are presented in Table 1.

Blood samples were collected from coccygeal vessels into sodium-heparinized Vacutainers (Becton Dickinson, Franklin Lakes, NJ) for all of the cows before

Table 1. Ingredient composition of the TMR fed to cows on both treatments in the prepartum and postpartum periods

\begin{tabular}{|c|c|c|}
\hline Ingredient, $\%$ of DM & Prepartum & Postpartum \\
\hline Corn silage & 42.55 & 31.65 \\
\hline Alfalfa hay & - & 10.55 \\
\hline Wet brewers grain & 12.77 & 10.55 \\
\hline Rye silage & 21.28 & - \\
\hline Corn meal & 4.26 & 16.87 \\
\hline Solvent-extracted soybean meal & 6.38 & 5.91 \\
\hline Whole cotton seed & — & 6.33 \\
\hline Citrus pulp & 8.5 & 12.66 \\
\hline Expeller soybean meal ${ }^{1}$ & - & 2.11 \\
\hline Mineral and vitamin $\operatorname{mix}^{2}$ & 4.26 & 3.38 \\
\hline
\end{tabular}

${ }^{1}$ SoyPLUS (West Central Coop., Ralston, IA).

${ }^{2}$ Mineral and vitamin mix prepartum included $21 \%$ CP, $2 \%$ crude fat, $13 \%$ crude fiber, $8.5 \% \mathrm{Ca}, 1 \% \mathrm{P}, 3 \% \mathrm{NaCl}, 3.5 \% \mathrm{Mg}, 4.4 \% \mathrm{~S}, 34 \mathrm{mg}$ of $\mathrm{Co} / \mathrm{kg}, 129 \mathrm{mg}$ of $\mathrm{Cu} / \mathrm{kg}, 15 \mathrm{mg}$ of I/ $\mathrm{kg}, 300 \mathrm{mg}$ of $\mathrm{Mn} / \mathrm{kg}, 7 \mathrm{mg}$ of $\mathrm{Se} / \mathrm{kg}, 435 \mathrm{mg}$ of $\mathrm{Zn} / \mathrm{kg}, 200 \mathrm{mg}$ of $\mathrm{F} / \mathrm{kg}, 220,459 \mathrm{IU}$ of vitamin $\mathrm{A} / \mathrm{kg}$, $70,000 \mathrm{IU}$ of vitamin $\mathrm{D}_{3} / \mathrm{kg}$, and $5,512 \mathrm{IU}$ of vitamin $\mathrm{E} / \mathrm{kg}$. Mineral and vitamin mix postpartum included $25 \% \mathrm{CP}, 0.25 \%$ crude fat, $1 \%$ crude fiber, $3 \% \mathrm{ADF}, 5.75 \% \mathrm{Ca}, 1.2 \% \mathrm{P}, 4.75 \% \mathrm{NaCl}, 9.25 \mathrm{mg}$ of $\mathrm{Se} /$ $\mathrm{kg}, 110,230 \mathrm{IU}$ of vitamin $\mathrm{A} / \mathrm{kg}, 39,683 \mathrm{IU}$ of vitamin $\mathrm{D}_{3} / \mathrm{kg}, 1,102 \mathrm{IU}$ of vitamin $\mathrm{E} / \mathrm{kg}$, and $381 \mathrm{mg}$ of monensin $/ \mathrm{kg}$. 
morning feeding $(0700 \mathrm{~h})$ at dry-off, $-32,-18,-7$, and $-3 \mathrm{~d}$, at calving, and at $2,14,28$, and $42 \mathrm{~d}$ relative to calving. Samples were immediately put in ice and centrifuged at $2,619 \times g$ at $4^{\circ} \mathrm{C}$ for 30 min within $1 \mathrm{~h}$ after collection. After centrifugation, the plasma samples were aliquoted and frozen until insulin and metabolite analyses.

\section{Metabolic Tests}

At dry-off, $-14,7$, and 28 d relative to calving, a subset of cows were subjected to metabolic tests (n $=16 ; 8$ cows per treatment). A catheter (14 gauge $\times$ $14 \mathrm{~cm}$ Abbocath-T; Hospira, Finisklin Business Park, Sligo, Ireland) was inserted into the jugular vein of each cow the day before the metabolic tests. An intravenous GTT was conducted on the first day of the metabolic tests and insulin challenge (IC) was performed on the following day. The actual dates for GTT were $-43 \pm$ $1.3,-12 \pm 1.1,8 \pm 0.4$ and $29 \pm 0.5 \mathrm{~d}$ relative to calving; and the actual dates for IC were $-42 \pm 1.3$, $-11 \pm 1.1,9 \pm 0.4$, and $30 \pm 0.5 \mathrm{~d}$ relative to calving. All metabolic tests were performed at noon following the morning milking and feeding. Additionally, all of the cows were fasted for $1 \mathrm{~h}$ before each test. The procedures of metabolic tests were based on those of Pires et al. (2008).

For the GTT, $0.25 \mathrm{~g} / \mathrm{kg}$ of BW of glucose (dextrose 50\%, wt/vol; Phoenix Scientific Inc., St. Joseph, MO) was infused into the jugular vein through the catheter followed by $50 \mathrm{~mL}$ of sterile saline solution to flush the catheter. The duration of glucose infusion was $5.6 \pm 0.2$ min. Blood samples were drawn through the catheter at $-15,-5$, and 0 min relative to the starting point of glucose infusion and $5,10,15,20,30,40,50,60,75$, $90,120,150$, and $180 \mathrm{~min}$ relative to the ending point of glucose infusion into Vacutainer tubes containing sodium fluoride and potassium oxalate (Becton Dickinson). Samples were immediately placed in the ice and centrifuged at $2,619 \times g$ at $4^{\circ} \mathrm{C}$ for 15 min within $1 \mathrm{~h}$ after collection. The catheter was flushed with sterile saline containing sodium heparin between samplings to avoid clotting and the first $3 \mathrm{~mL}$ of blood collection was discarded before each subsequent sample.

The IC was performed by administering $0.1 \mathrm{IU}$ of insulin $/ \mathrm{kg}$ of BW (100 IU/mL, human insulin, rDNA origin; Eli Lilly and Co., Indianapolis, IN) through the jugular catheter, followed by $50 \mathrm{~mL}$ of sterile saline solution. The duration of insulin infusion was $2.7 \pm 0.1$ min. Blood samples were collected at $-15,-5$, and 0 min relative to the starting point of insulin administration and $5,10,15,20,25,30,45,60,75,90$, and 120 min relative to the ending point of insulin administration through the catheter.

\section{Insulin and Metabolite Analyses}

The concentration of insulin in the plasma samples was determined by RIA (Malven et al., 1987), and the inter- and intraassay CV were 12.8 and $7.3 \%$, respectively. Plasma glucose (Autokit Glucose; Wako Chemicals USA Inc., Richmond, VA) and NEFA [HR Series NEFA-HR(2), Wako Chemicals USA Inc., Richmond, VA] concentrations were measured by enzymatic methods. The inter- and intraassay CV were 10 and $7.1 \%$, respectively, for glucose assays, and 5.1 and $3.2 \%$, respectively, for NEFA assays.

\section{Calculations and Statistical Analysis}

The observed concentrations of insulin and metabolites from GTT and IC to 180 and 120 min, respectively, were used to create response curves. The area under each of these curves (AUC) was calculated by the trapezoidal method in which the insulin or metabolite concentration value was calculated by subtracting the baseline value from the actual value. The mean value of the insulin or metabolite concentration of the samples collected at $-15,-5$, and 0 min relative to glucose or insulin infusion was considered as the baseline value. The accumulated AUC of insulin and metabolites at 30, 60, and $180 \mathrm{~min}$ in the GTT and at 30, 60 and 120 min in the IC were calculated and analyzed.

To calculate the dates of metabolic tests, PROC UNIVARIATE of SAS 9.2 (SAS Institute Inc., Cary, $\mathrm{NC}$ ) was used and the means \pm standard error of the mean are reported. The temperature-humidity index was calculated by the PROC UNIVARIATE and the means \pm standard deviation are reported. Parity, dry period length, and gestation length were analyzed by the PROC GLM of SAS 9.2 and data are reported as least squares means \pm standard error of the mean. Repeated measures data (rectal temperature, respiration rate, milk production, milk composition, DMI, cumulative BW change, cumulative BCS change, BW after 6 wk postpartum, feed efficiency, blood concentrations of insulin, and metabolites) were analyzed using the PROC MIXED procedure of SAS 9.2. The SAS model included fixed effects of treatment, time, and treatment by time interaction, with cow (treatment) as the random effect and the least squares means \pm standard error of the mean are reported. To separate the treatment and posttreatment effects, data from cumulative BW change, cumulative BCS change, DMI, blood concentrations of insulin, and metabolites were split into prepartum and postpartum periods and analyzed separately. The BW at dry-off and calving were used as covariates and included in the SAS models of prepartum and postpartum DMI analyses, respectively, 
TAO ET AL.

Table 2. Dry period length, gestation length, rectal temperatures, and respiration rate of cows exposed to either heat stress $(\mathrm{n}=16)$ or cooling $(\mathrm{n}=16)$ during the dry period

\begin{tabular}{lcccc}
\hline Variable & Heat stress & Cooling & SEM & $P$-value \\
\hline Dry period length, d & 40.4 & 44.3 & 1.5 & 0.08 \\
Gestation length, d & 272 & 276 & 1.2 & 0.02 \\
Rectal temperature a.m., ${ }^{\circ} \mathrm{C}$ & 38.64 & 38.55 & 0.04 & 0.12 \\
Rectal temperature p.m., ${ }^{\circ} \mathrm{C}$ & 39.34 & 38.98 & 0.05 & $<0.01$ \\
Respiration rate, breath/min & 69.2 & 48.3 & 2.8 & $<0.01$ \\
\hline
\end{tabular}

to minimize the effect of BW on DMI. In addition, the samples collected at dry-off were included in the SAS model as covariates for statistical analyses of blood concentrations of insulin and metabolites during the prepartum period. The accumulated AUC at 30,60 , and $180 \mathrm{~min}$ in the GTT and at 30, 60, and $120 \mathrm{~min}$ in the IC were analyzed individually using the PROC MIXED procedure. The SAS models included fixed effects of treatment, day relative to calving, and treatment by day relative to calving interaction, with cow (treatment) as the random effect. Least squares means \pm standard error of the mean are reported. In addition, the data of accumulated AUC at dry-off were considered as covariates and included in the analyses. The insulin and metabolite concentration in plasma of each metabolic test within each test day were analyzed using the PROC MIXED procedure. The SAS models included fixed effects of treatment, time relative to infusion, and treatment by time relative to infusion interaction, with cow (treatment) as the random effect and the baseline value of insulin and metabolite concentrations of plasma was also included in the SAS model as covariates. Least squares means \pm standard error of the mean are reported. For all of the covariate analyses, if the effect of the covariate was not significant $(P>0.3)$, the covariate was removed from the model.

\section{RESULTS}

\section{Thermal Environment, Rectal Temperature, Respiration Rate, and Dry Period and Gestation Length}

The stall areas for both HT and CL cows had a similar temperature-humidity index $(78.3, \mathrm{SD}=4.2)$ during the dry period, which indicates that both groups of cows were exposed to a similar thermal environment. Compared with HT cows, CL cows tended $(P=0.12)$ to have decreased rectal temperature in the morning and had lower $(P<0.01)$ rectal temperature and respiration rate in the afternoon (Table 2 ). Additionally, the dry period length of HT cows tended $(P=0.08)$ to be $4 \mathrm{~d}$ shorter, which was caused by a $4 \mathrm{~d}$ reduction $(P=$ 0.02 ) in gestation length relative to CL cows (Table 2).

\section{Milk Production and Composition}

Compared with HT cows, CL cows produced $6.3 \mathrm{~kg} / \mathrm{d}$ more milk $(P<0.01$; Figure 1$)$ until 42 wk postpartum. No treatment effect was observed for concentrations of milk fat, protein, or lactose or for SCS (Table 3). However, with the higher milk production, cows cooled during the dry period had greater $(P \leq 0.01)$ yields of milk fat, protein, and lactose compared with HT cows (Table 3).

\section{DMI, BW, BCS, and Feed Efficiency}

Cooling heat-stressed cows during the dry period tended $(P \leq 0.10)$ to increase DMI during the prepartum and postpartum periods (Figure 2). Additionally, no difference was observed between treatments in the DMI during the first $14 \mathrm{~d}$ after calving (15.2 vs. 14.3 $\mathrm{kg} / \mathrm{d}$ for CL and HT cows, respectively); however, CL cows consumed more $(P=0.04)$ DM compared with HT cows after 2 wk postpartum (19.7 vs. $17.6 \mathrm{~kg} / \mathrm{d}$ for CL and HT cows, respectively). Relative to HT, CL cows gained more $(P=0.01)$ weight before calving and

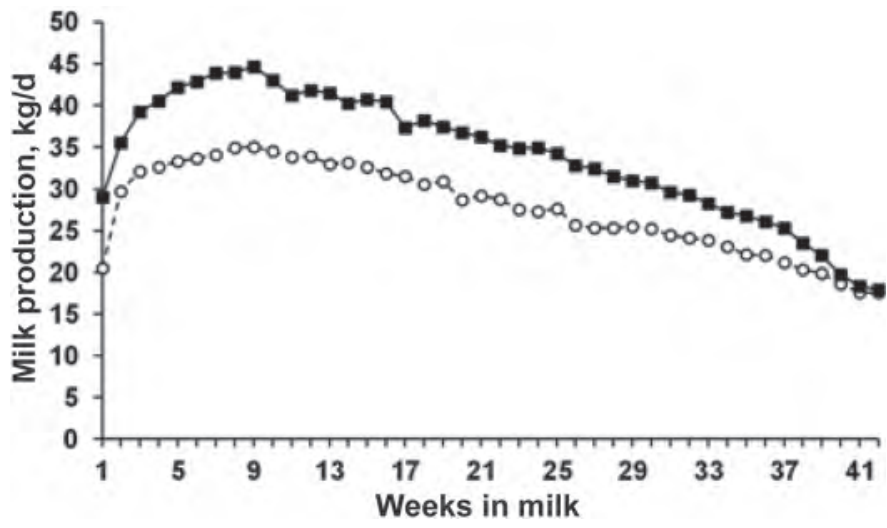

Figure 1. Effect of cooling heat-stressed cows $(\mathrm{n}=16 /$ treatment $)$ during the dry period on milk production up to $42 \mathrm{wk}$ postpartum in the subsequent lactation. Solid squares $(\boldsymbol{\square})$ and open circles $(\bigcirc)$ represent cooled cows and heat-stressed cows, respectively. After calving, all cows were managed and housed under the same conditions. Effect of treatment: $P<0.01$, time: $P<0.01$, and treatment by time interaction: $P=0.11$. 
Table 3. Milk composition, BW and BCS change, and feed efficiency of cows exposed to heat stress $(\mathrm{n}=16)$ or cooling $(\mathrm{n}=16)$ during the dry period

\begin{tabular}{lcccc}
\hline Variable & Heat stress & Cooling & SEM & $P$-value \\
\hline Milk fat, \% & 3.69 & 3.61 & 0.07 & 0.43 \\
Milk protein, \% & 3.05 & 3.08 & 0.05 & 0.68 \\
Milk lactose, \% & 4.67 & 4.69 & 0.02 & 0.54 \\
Milk fat yield, kg/d & 0.98 & 1.21 & 0.06 & 0.01 \\
Milk protein yield, kg/d & 0.82 & 1.04 & 0.05 & $<0.01$ \\
Milk lactose yield, kg/d & 1.27 & 1.61 & 0.09 & 0.01 \\
Milk SCS & 3.16 & 2.89 & 0.18 & 0.67 \\
BW change prepartum, ${ }^{1}{ }^{2 g}$ & 9.6 & 26.0 & 4.5 & 0.01 \\
BW change postpartum ${ }^{2}$ kg & -46.9 & -72.4 & 7.5 & 0.02 \\
BCS change prepartum $^{3}$ & -0.05 & 0.02 & 0.05 & 0.42 \\
BCS change postpartum $^{4}$ & -0.21 & -0.34 & 0.07 & 0.14 \\
Feed efficiency $^{5}$ & 1.90 & 2.23 & 0.08 & $<0.01$ \\
\hline
\end{tabular}

${ }^{1}$ Prepartum accumulative BW change was calculated by subtracting data at $-5,-4,-3,-2$, and -1 wk relative to calving and calving by data at dry-off.

${ }^{2}$ Postpartum accumulative BW change was calculated by subtracting data at 1,2, 3, 4, 5, and 6 wk relative to calving by data at calving.

${ }^{3}$ Prepartum accumulative BCS change was calculated by subtracting data at $-5,-4,-3,-2$, and -1 wk relative to calving and calving by data at dry-off.

${ }^{4}$ Postpartum accumulative BCS change was calculated by subtracting data at $1,2,3,4,5$, and 6 wk relative to calving by data at calving.

${ }^{5}$ Feed efficiency $=$ kilograms of 3.5\% FCM per kilogram of DMI. Feed efficiency was calculated from calving until 6 wk postpartum.

lost more $(P=0.02)$ weight in early lactation (Table 3). Nevertheless, no treatment effect on BW after $6 \mathrm{wk}$ postpartum was observed and the mean BW were 654.7 \pm 12.2 and $662.9 \pm 11.6 \mathrm{~kg}$ for HT and CL, respectively. During the dry period, treatment did not affect BCS change; however, CL cows tended $(P=0.14)$ to lose more body condition compared with HT cows in early lactation (Table 3). After calving, CL cows had higher $(P<0.01)$ feed efficiency relative to HT cows within 6 wk postpartum (Table 3 ).

\section{Insulin and Blood Metabolites}

Plasma insulin and glucose concentrations were similar between treatments during the prepartum period (Figure 3), but cooling heat-stressed cows during the dry period tended $(P=0.12)$ to decrease circulating insulin and lowered $(P=0.01)$ plasma glucose concentration during the postpartum period (Figure 3). Cows from the CL treatment had increased $(P=0.03)$ circulating NEFA in early lactation compared with HT cows (Figure 3$)$. Additionally, a tendency $(P=0.06)$ of treatment by time effect occurred for circulating NEFA during the prepartum period, such that CL cows had higher circulating NEFA at parturition compared with HT (Figure 3).

\section{Metabolic Tests}

No differences of effects of treatment or treatment by day interaction were observed for insulin AUC dur- ing the GTT during the transition period (Table 4). Regardless of treatments, cows during the dry period had greater AUC for insulin in response to the GTT compared with measurements taken in early lactation. No overall treatment effects were observed for the glucose AUC to the GTT during the transition period (Table 4). However, the glucose AUC tended $(P \leq$ $0.15)$ to be larger for CL cows at $7 \mathrm{~d}$ relative to calving compared with HT cows (Table 4; Figure 4). In addi-

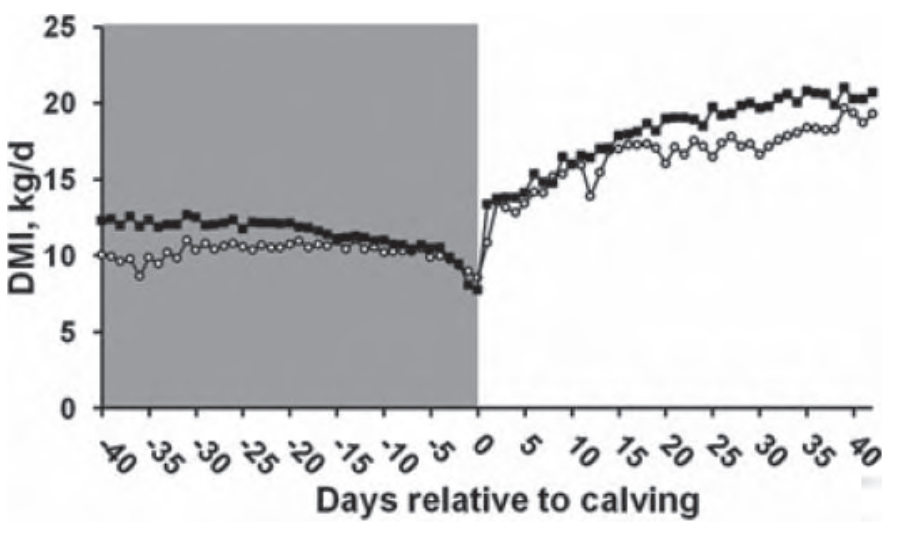

Figure 2. Effect of cooling heat-stressed cows $(n=16 /$ treatment $)$ during the dry period on the DMI from -40 to $42 \mathrm{~d}$ relative to calving. Solid squares $(\square)$ and open circles $(\bigcirc)$ represent cooled cows and heatstressed cows, respectively. Data were split into prepartum and postpartum and analyzed separately. During the prepartum period, the effect of treatment was $P=0.06$, time was $P<0.01$, and treatment by time interaction was $P=0.60$; during the postpartum period, the effect of treatment was $P=0.10$, time was $P<0.01$, and treatment by time interaction was $P=0.38$. Shade represents the prepartum period. 

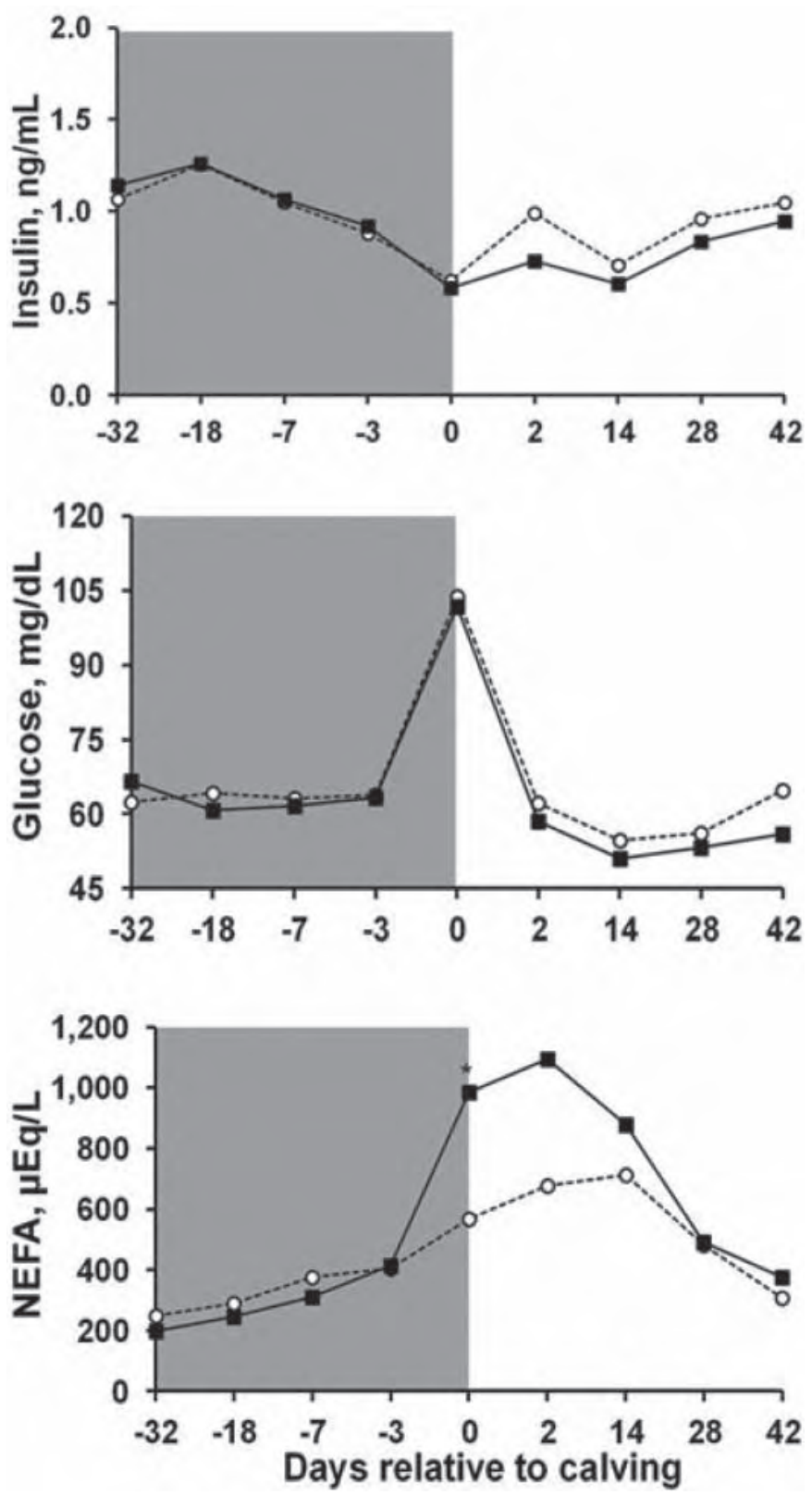

Figure 3. Effect of cooling heat-stressed cows $(\mathrm{n}=16 /$ treatment $)$ during the dry period on the insulin, glucose, and NEFA concentrations of plasma. Solid squares $(\boldsymbol{\square})$ and open circles $(O)$ represent cooled cows and heat-stressed cows, respectively. Data were split into prepartum and postpartum and analyzed separately. In the insulin analysis, during the prepartum period, the effect of treatment was $P$ $=0.94$, time was $P<0.01$, and treatment by time interaction was $P$ $=0.99$; during the postpartum period, the effect of treatment was $P=$ 0.12 , time was $P<0.01$, and treatment by time interaction was $P=$ 0.50 . In the glucose analysis, during the prepartum period, the effect of treatment was $P=0.99$, time was $P<0.01$, and treatment by time interaction was $P=0.58$; during the postpartum period, the effect of treatment was $P=0.01$, time was $P<0.01$, and treatment by time interaction was $P=0.28$. In the NEFA analysis, during the prepartum period, the effect of treatment was $P=0.70$, time was $P<0.01$, and treatment by time interaction was $P=0.06$; during the postpartum period, the effect of treatment was $P=0.03$, time was $P<0.01$, and treatment by time interaction was $P=0.15$. Shade represents the prepartum period. ${ }^{*} P<0.05$. tion, the glucose AUC was greater $(P \leq 0.01)$ for cows during the dry period compared with early lactation (Table 4).

Cooling heat-stressed prepartum cows did not affect the insulin clearance after IC pre- and postpartum (Table 5). Day effects for insulin AUC to IC at 30 and 60 min were observed, as cows in late gestation had greater $(P<0.01$ and $P=0.02$, respectively) insulin AUC relative to early lactation (Table 5 ). A tendency $(P=0.09)$ of treatment by day effect of glucose AUC to IC at 60 min was observed, such that CL cows tended to have weaker glucose response to IC compared with HT cows at $7 \mathrm{~d}$ relative to calving (Table 5; Figure $5)$. The NEFA response to IC was affected by the day $(P<0.01)$, as the cows in early lactation had an increase in NEFA AUC compared with those values in the dry period and cows at $7 \mathrm{~d}$ relative to calving had the strongest response (Table 5). In addition, a treatment by day interaction $(P=0.02)$ was observed for the NEFA AUC to IC at $30 \mathrm{~min}$, as the CL cows had stronger NEFA response to IC during the postpartum period compared with HT cows (Table 5; Figure 6).

\section{DISCUSSION}

All of the cows in the present study were exposed to similar thermal stress during the dry period, but the cooling system effectively minimized the heat load on CL cows compared with HT cows as indicated by the decreased rectal temperature and respiration rate. Similar to other reports (do Amaral et al., 2009, 2011), the longer gestation length and dry period length of CL cows also provide further evidence that the CL cows were less heat stressed than HT cows during the dry period. Therefore, the heat stress model in the present experiment was appropriate to evaluate the hypothesis that cooling heat-stressed cows during the dry period decreases the insulin responsiveness of peripheral tissues during the transition period.

The increase in milk production of cooled cows relative to heat-stressed cows was expected and consistent with previous reports (Wolfenson et al., 1988). The higher milk synthesis in the subsequent lactation results from the increased mammary gland development during the dry period due to heat stress abatement (Tao et al., 2011). Specifically, CL cows have higher mammary cell proliferation during the dry period relative to HT cows.

The lack of effect of cooling heat-stressed cows during the dry period on the concentration of milk fat is not consistent with earlier reports and may result from differences in the duration of sample collection. When milk samples were collected until only 6 to 8 wk postpartum, do Amaral et al. $(2009,2011)$ and 
Table 4. Insulin and glucose responses to glucose tolerance tests of cows exposed to heat stress (HT, n $=8)$ or cooling (CL, $\mathrm{n}=8)$ during the dry period

\begin{tabular}{|c|c|c|c|c|c|c|c|c|c|c|}
\hline \multirow[b]{2}{*}{ Item } & \multicolumn{2}{|c|}{$-14 d^{1}$} & \multicolumn{2}{|c|}{$7 \mathrm{~d}$} & \multicolumn{2}{|c|}{$28 \mathrm{~d}$} & \multirow[b]{2}{*}{ SEM } & \multicolumn{3}{|c|}{$P$-value } \\
\hline & $\mathrm{HT}$ & CL & $\mathrm{HT}$ & CL & $\mathrm{HT}$ & CL & & $\mathrm{TRT}^{2}$ & Day & TRT $\times$ day \\
\hline \multicolumn{11}{|c|}{ Insulin $\mathrm{AUC},{ }^{3} \mathrm{ng} \times \mathrm{min} / \mathrm{mL}$} \\
\hline $30 \min$ & 158 & 148 & 87 & 90 & 79 & 95 & 20 & 0.90 & $<0.01$ & 0.62 \\
\hline $60 \min$ & 225 & 218 & 110 & 115 & 102 & 117 & 22 & 0.86 & $<0.01$ & 0.82 \\
\hline 180 min & 218 & 196 & 112 & 99 & 89 & 113 & 22 & 0.88 & $<0.01$ & 0.37 \\
\hline \multicolumn{11}{|c|}{ Glucose AUC, $\mathrm{mg} \times \min / \mathrm{dL}$} \\
\hline $180 \mathrm{~min}$ & 3,611 & 2,508 & 1,758 & 3,256 & 1,567 & 1,864 & 609 & 0.75 & 0.01 & 0.05 \\
\hline
\end{tabular}

${ }^{1}$ Days relative to calving.

${ }^{2} \mathrm{TRT}=$ treatment.

${ }^{3} \mathrm{AUC}=$ area under the curve.

Avendaño-Reyes et al. (2006) reported that CL cows had increased milk fat concentration compared with HT cows. However, when sample collection extended beyond early lactation (Adin et al., 2009) and into late lactation (Tao et al., 2011), no difference in fat concentration was observed. In other words, the increased milk fat concentration that results from cooling heatstressed dry cows is limited to early lactation and the effect is lost if the entire lactation is considered. Consistent with that interpretation, in the present study, CL cows had higher $(P=0.07)$ milk fat concentration in the first 4 wk postpartum (3.92 vs. $3.75 \%$, respectively) compared with HT cows, but no difference was observed between treatments when analyzed for the full 42 wk postpartum.

As previously reported (do Amaral et al., 2009; Tao et al., 2011), cooling heat-stressed cows increases DMI during the dry period. Additionally, CL cows tended to consume more DM relative to HT cows during the postpartum period. This increased nutrient intake may reflect the higher milk production of CL cows compared with HT cows. do Amaral et al. (2009, 2011) reported that cooling heat-stressed dry cows did not affect the DMI during the first $6 \mathrm{wk}$ of the postpartum period; however, in those experiments, the pronounced milk production difference only appeared after 7 wk of lactation. In the present study, CL cows produced more milk compared with HT cows from the beginning of the lactation. The higher BW gain during the dry period for CL cows relative to HT cows is consistent with other reports (do Amaral et al., 2009; Tao et al., 2011) and may reflect the higher DMI. The fact that CL cows lost more BW and body condition in the postpartum period compared with HT cows suggests that CL cows have more body fat to mobilize in early lactation relative to HT cows.

Similar to results from earlier studies (Collier et al., 1982b; Urdaz et al., 2006; do Amaral et al., 2009), the glucose, NEFA, and insulin concentrations during late gestation were not affected by treatments. Under the same level of nutrition, heat-stressed midlactation cows have compromised adipose tissue mobilization (Baumgard et al., 2011) and lower circulating NEFA (Wheelock et al., 2010) compared with those under thermoneutral conditions, even though both groups of cows have a similar negative energy balance. In the current study, the similar body condition change and NEFA concentration between HT and CL cows during the dry period indicate that the decreased fat mobilization of heat-stressed cows in midlactation did not occur in late gestation. The discrepancy between heat-stressed midlactation and dry cows is still not clear and likely reflects differences of energy status at different points in the production cycle. In midlactation, the heatstressed cows are in negative energy balance because of a decrease in DMI (Wheelock et al., 2010). In contrast, heat-stressed dry cows may remain in positive energy balance because the energy cost of pregnancy is much less than that of lactation (NRC, 2001). Indeed, in late lactation, the heat-stressed cow stays in positive energy balance (Kim et al., 2010) and has similar circulating NEFA compared with cooled cows (Tarazón-Herrera et al., 1999). Thus, the difference of the energy status of midlactation versus dry cows may be responsible to the variable NEFA responses to heat stress.

After parturition, CL cows had lower circulating glucose compared with HT cows. Although CL cows consumed more DM in early lactation, the higher milk lactose output due to the higher milk production may explain the decreased circulating glucose of CL cows relative to HT cows. The increased circulating NEFA in the CL cows relative to HT cows at parturition and in early lactation indicates upregulated body fat mobilization and is consistent with previous work (do Amaral et al., 2009). At the onset of lactation, adipose tissue mobilization is an important adaptation of nu- 

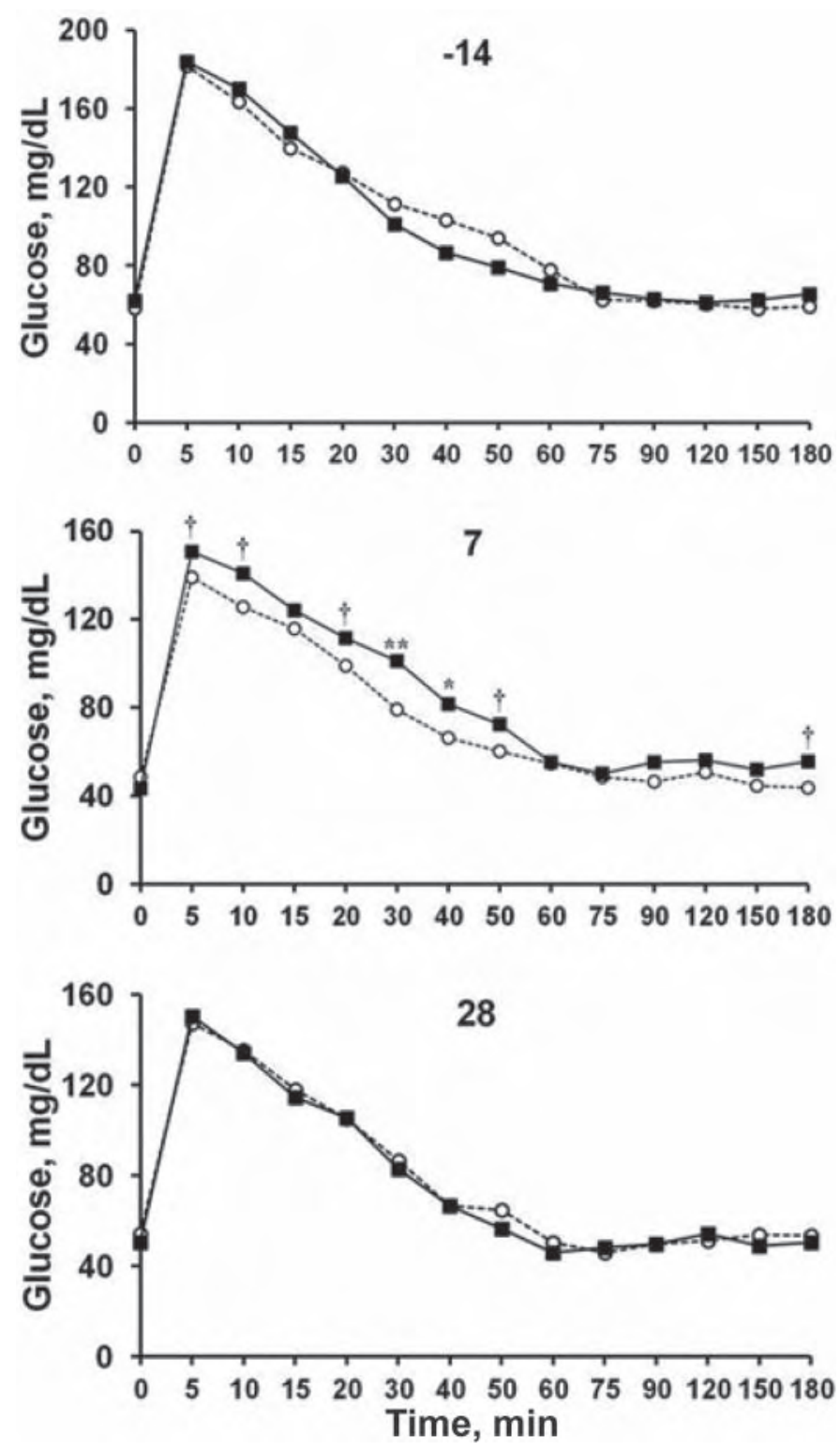

Figure 4. Effect of cooling heat-stressed cows $(n=8 /$ treatment $)$ during the dry period on plasma glucose response to the glucose tolerance test at $-14,7$, and $28 \mathrm{~d}$ relative to calving. Solid squares ( and open circles $(\bigcirc)$ represent cooled cows and heat-stressed cows, respectively. After calving, all cows were managed and housed under the same conditions. At $-14 \mathrm{~d}$ relative to calving, the effect of treatment was $P=0.81$, minute was $P<0.01$, and treatment by minute interaction was $P=0.50$. At $7 \mathrm{~d}$ relative to calving, the effect of treatment was $P=0.15$, minute was $P<0.01$, and treatment by minute interaction was $P=0.05$. At $28 \mathrm{~d}$ relative to calving, the effect of treatment was $P=0.56$, minute was $P<0.01$, and treatment by minute interaction was $P=0.44$. ${ }^{* *} P<0.01 ;{ }^{*} P<0.05 ; \nmid P<0.15$

trient partitioning to support milk synthesis (Bauman and Currie, 1980; Vernon and Pond, 1997). Thus, the increased body fat mobilization may reflect the higher nutrient demand for milk production in CL cows. Moreover, the higher DMI during the dry period may be another reason for the extensive fat mobilization of CL cows because the magnitude of the adipose tissue mobilization in early lactation is related to the level of nutrient intake in the dry period (Holtenius et al., 2003). Physiologically, the lower circulating insulin of CL cows relative to HT cows in early lactation is consistent with higher NEFA because insulin is an antilipolytic factor and enhances lipogenesis (Bell, 1995; Hayirli, 2006).

In midlactation, heat-stressed cows appear to have a preference to use glucose as an oxidative substrate and the increased insulin response shunts glucose into other peripheral tissues at the expense of the mammary gland (Wheelock et al., 2010; Baumgard et al., 2011). Whether this altered glucose sparing mechanism observed in midlactation cows under heat stress occurs at all lactation stages is unknown. In the current study, the glucose clearance rate of GTT was not affected by treatments during the dry period. Glucose disposal rate in the GTT is dependent on decreased glucose production and increased utilization (Hayirli et al., 2001). With similar insulin response to GTT, both groups of cows may have similar decreases in hepatic glucose output because insulin is a potent inhibitor of hepatic gluconeogenesis and glycogenolysis (Hayirli, 2006). Therefore, both groups of cows likely have similar glucose utilization following the GTT during the dry period. Additionally, similar glucose responses to IC between treatments during the dry period indicate similar glucose utilization at peripheral tissues for HT and CL cows, which is in contrast to the increased glucose utilization in the heat-stressed midlactation cows. The differences in insulin action on the peripheral tissues and glucose metabolism between heat-stressed cows in midlactation and the dry period may result from variable glucose balance in different lactation stages. The glucose demand for milk lactose synthesis in lactation is much higher compared with the gravid uterus glucose requirement for the fetal growth in late gestation (Bell, 1995; Drackley et al., 2001). Thus, the heat-stressed midlactation cows may be under negative glucose balance due to the decrease in DMI relative to thermoneutral cows. On the other hand, even though DMI decreases during heat stress in dry cows, they likely remain in positive glucose balance because of the lesser glucose demand by the gravid uterus compared with lactose synthesis. The increased insulin action on peripheral tissues observed in the heat-stressed midlactation cows may not, therefore, be activated in dry cows.

Insulin resistance at peripheral tissues is one of the homeorhetic mechanisms active in early lactation to spare glucose from adipose and muscle tissues to the mammary gland to satisfy the enormous glucose demand for milk synthesis (Bell, 1995; Bell and Bauman, 
Table 5. Insulin, glucose, and NEFA responses to insulin challenges of cows exposed to heat stress $(\mathrm{HT}, \mathrm{n}=8)$ or cooling $(\mathrm{CL}, \mathrm{n}=8)$ during the dry period

\begin{tabular}{|c|c|c|c|c|c|c|c|c|c|c|}
\hline Item & \multicolumn{2}{|c|}{$-14 d^{1}$} & \multicolumn{2}{|c|}{$7 \mathrm{~d}$} & \multicolumn{2}{|c|}{$28 \mathrm{~d}$} & SEM & \multicolumn{3}{|c|}{$P$-value } \\
\hline \multicolumn{11}{|l|}{ Insulin $\mathrm{AUC},{ }^{3} \mathrm{ng} \times \mathrm{min} / \mathrm{mL}$} \\
\hline $30 \mathrm{~min}$ & 141 & 151 & 119 & 124 & 121 & 125 & 7 & 0.47 & $<0.01$ & 0.86 \\
\hline $60 \min$ & 160 & 175 & 149 & 149 & 144 & 149 & 10 & 0.54 & 0.02 & 0.65 \\
\hline $120 \mathrm{~min}$ & 130 & 152 & 149 & 154 & 136 & 145 & 14 & 0.29 & 0.72 & 0.68 \\
\hline \multicolumn{11}{|l|}{ Glucose AUC, $\mathrm{mg} \times \mathrm{min} / \mathrm{dL}$} \\
\hline \multirow{2}{*}{\multicolumn{11}{|c|}{ NEFA AUC, $\mu \mathrm{Eq} \times \min / \mathrm{dL}$}} \\
\hline & & & & & & & & & & \\
\hline $30 \mathrm{~min}$ & -576 & -528 & $-2,670$ & $-4,655$ & $-1,285$ & $-2,973$ & 435 & 0.01 & $<0.01$ & 0.02 \\
\hline $60 \mathrm{~min}$ & -835 & 284 & $-6,194$ & $-12,247$ & 390 & $-4,289$ & 1,494 & 0.01 & $<0.01$ & 0.06 \\
\hline $120 \mathrm{~min}$ & 8,476 & 9,850 & $-2,834$ & $-19,417$ & 8,534 & 1,203 & 4,312 & 0.05 & 0.01 & 0.22 \\
\hline
\end{tabular}

${ }^{1}$ Days relative to calving.

${ }^{2} \mathrm{TRT}=$ treatment.

${ }^{3} \mathrm{AUC}=$ area under the curve.

1997). In the present experiment, the similar insulin response to the GTT, coupled with the slower glucose clearance during the GTT of CL cows compared with HT cows probably indicates that the CL cows had decreased glucose utilization compared with HT cows at 7 d relative to calving. Major routes for glucose flow after GTT in early lactation cows include peripheral tissues and the mammary gland. Whether or not mammary blood flow or glucose transporter distribution in the mammary gland in early lactation are altered by late gestation heat stress is unknown; however, the higher lactose production suggests that the mammary glands of CL cows have higher ability to sequester glucose compared with HT cows. Alternatively, CL cows may have decreased glucose utilization in peripheral tissues compared with HT cows in early lactation. The reduced glucose response to IC at $7 \mathrm{~d}$ relative to calving is also consistent with lower insulin sensitivity of peripheral tissues of CL cows relative to HT cows. The weaker insulin effects on the peripheral tissues in CL cows compared with HT cows may reflect the higher glucose demand for the milk lactose synthesis in CL cows. Even though CL cows consumed more feed compared with HT cows in the postpartum period, the differences of DMI did not appear until $14 \mathrm{~d}$ after calving. In the first week of lactation, with similar nutrient intake, the reduced insulin effect on peripheral tissues of CL cows may be an important homeorhetic adaptation to further spare glucose for mammary lactose synthesis compared with HT cows. However, after $14 \mathrm{~d}$ relative to calving, the greater DMI of CL cows provides more dietary glucose substrate for hepatic gluconeogenesis relative to that of HT cows. The similar insulin responses at peripheral tissues between treatments at 28 $\mathrm{d}$ relative to calving suggest that the insulin resistance of CL cows was overcome by increased DMI relative to HT cows as lactation advanced.

The observation that CL cows had a stronger NEFA response to IC compared with HT cows in early lactation indicates that CL cows have higher adipose tissue responsiveness to insulin relative to HT cows, at least with regard to lipolytic processes. This result is surprising, considering the fact that CL cows had higher basal circulating NEFA and reduced effects of insulin on peripheral tissues in terms of glucose metabolism compared with HT cows in early lactation. The insulin response during a GTT results from insulin release and turnover and the insulin clearance during an IC reflects the insulin degradation rate. In the present study, cooling heat-stressed cows during the dry period did not affect the insulin response to the GTT or clearance to IC during either the dry period or early lactation. These findings suggest that both groups of cows had similar pancreatic sensitivity to glucose and insulin degradation during the transition period. This may also indicate that the variable tissue responsiveness to insulin of HT and CL cows in early lactation is due to an alteration at the postreceptor level (Kahn, 1978).

The altered insulin response at peripheral tissues in HT compared with CL cows in early lactation likely results from differences in homeorhetic adaptation to the different milk synthetic capacity between HT and CL cows. As a result of higher mammary gland development during the dry period (Tao et al., 2011), the CL cows produce more milk and require higher total nutrients for milk synthesis relative to HT cows in the subsequent lactation. Based on DMI, the cows had similar nutrient intake in early lactation, but it is clear that more nutrients partition to the mammary gland in CL cows relative to HT cows. In the present study, 

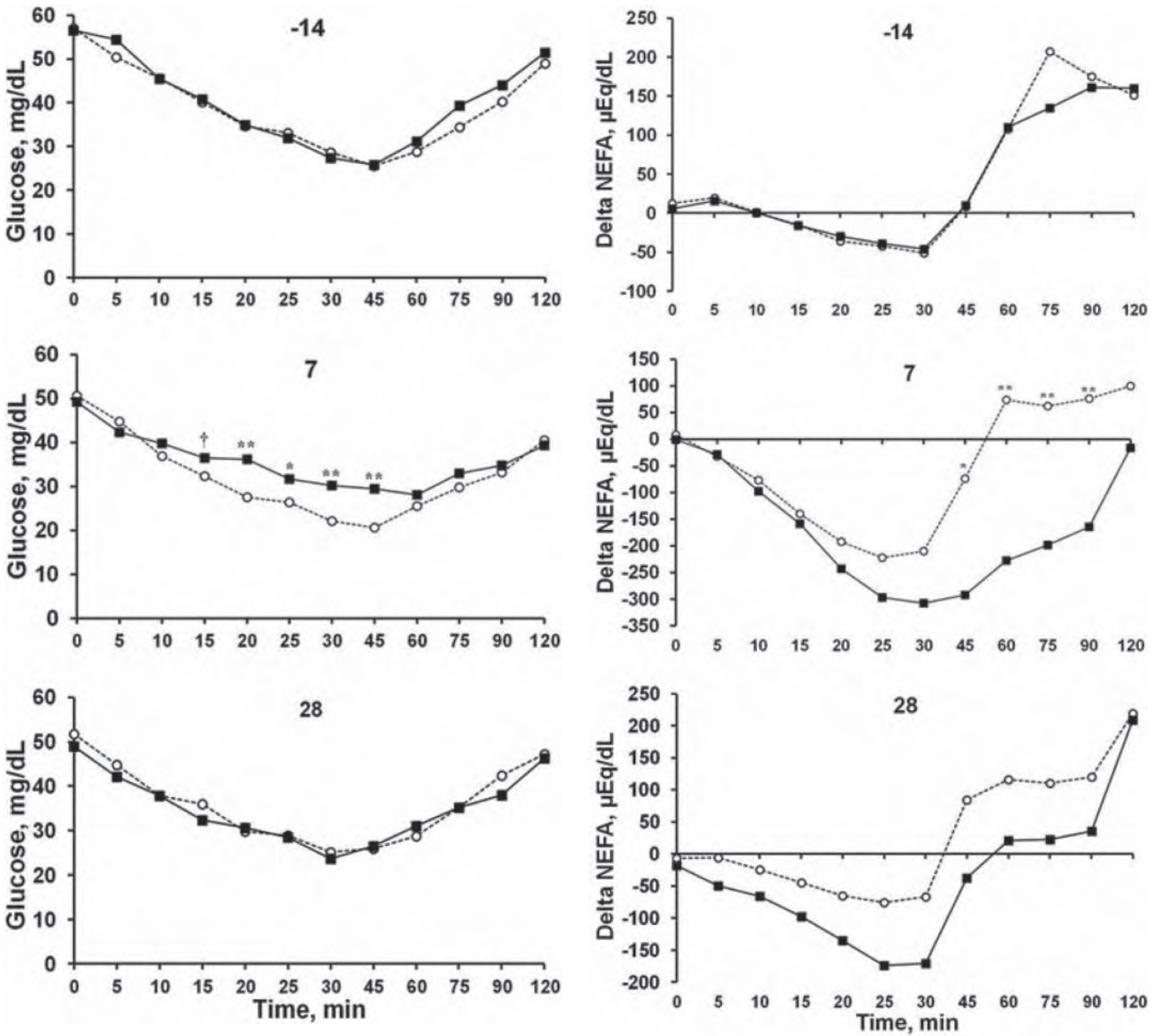

Figure 5. Effect of cooling heat-stressed cows $(\mathrm{n}=8 /$ treatment $)$ during the dry period on plasma glucose responses to insulin challenge at $-14,7$, and $28 \mathrm{~d}$ relative to calving. Solid squares (ם) and open circles $(\bigcirc)$ represent cooled cows and heat-stressed cows, respectively. After calving, all cows were managed and housed under the same conditions. At $-14 \mathrm{~d}$ relative to calving, the effect of treatment was $P=$ 0.41 , minute was $P<0.01$, and treatment by minute interaction was $P=0.46$. At $7 \mathrm{~d}$ relative to calving, the effect of treatment was $P=$ 0.01 , minute was $P<0.01$, and treatment by minute interaction was $P=0.01$. At $28 \mathrm{~d}$ relative to calving, the effect of treatment was $P=$ 0.36 , minute was $P<0.01$, and treatment by minute interaction was $P=0.54$. $* * P<0.01 ; * P<0.05 ; \dagger P<0.15$.

Figure 6. Effect of cooling heat-stressed cows $(\mathrm{n}=8 /$ treatment $)$ during the dry period on plasma NEFA response to insulin challenge at $-14,7$, and $28 \mathrm{~d}$ relative to calving. Solid squares (ם) and open circles $(\bigcirc)$ represent cooled cows and heat-stressed cows, respectively. After calving, all cows were managed and housed under the same conditions. Delta NEFA was calculated by subtracting data from samples collected at 0 to 120 min relative to insulin infusion by the average of data from samples taken at $-15,-5$ and 0 relative to insulin infusion. At $-14 \mathrm{~d}$ relative to calving, the effect of treatment was $P=0.96$, minute was $P<0.01$, and treatment by minute interaction was $P=$ 0.95 . At $7 \mathrm{~d}$ relative to calving, the effect of treatment was $P=0.11$, minute was $P<0.01$, and treatment by minute interaction was $P<$ 0.01 . At $28 \mathrm{~d}$ relative to calving, the effect of treatment was $P=0.09$, minute was $P<0.01$, and treatment by minute interaction was $P=$ 0.36. ${ }^{* *} P<0.01 ;{ }^{*} P<0.05$. 
at least part of the enhanced homeorhetic regulation in CL cows was mediated by lower basal circulating insulin and decreased insulin responses at peripheral tissues. This allows the greater mammary capacity for milk synthesis (Tao et al., 2011) to be realized and CL cows to produce more milk.

The physiological reason for the altered metabolic adaptations and insulin effects on peripheral tissues between treatments in early lactation is unknown, but may partly be due to the effects of growth hormone (GH). In the current study, the higher circulating NEFA in early lactation likely indicates that the CL cows have higher homeorhetic control by GH compared with HT cows because GH is correlated with FA mobilization and circulating NEFA (Etherton and Bauman, 1998). The observation of do Amaral et al. (2009) of increased hepatic suppressors of cytokine signaling 3 gene expression $2 \mathrm{~d}$ after calving in prepartum cooled cows compared with noncooled cows provides additional evidence that the CL cows have increased GH in early lactation compared with HT cows because somatotropin administration during lactation dramatically increases the hepatic suppressors of cytokine signaling 3 mRNA abundance (Rhoads et al., 2010). Growth hormone increases FA mobilization by increasing catecholamine-stimulated lipolysis and decreasing insulin-mediated lipogenesis in adipose tissue (Sechen et al., 1990; Etherton and Bauman, 1998). Thus, an increase in GH coupled with a decrease in circulating insulin in early lactation provides a physiological explanation for the greater FA mobilization of CL cows compared with HT cows. In addition to an inhibitory effect on insulin-stimulated lipogenesis in adipose tissue, GH enhances the anti-lipolytic effect of insulin (Sechen et al., 1990; Etherton and Bauman, 1998), which may explain the stronger NEFA response to IC of CL cows compared with HT cows in early lactation. Growth hormone alters nutrient partitioning by increasing insulin resistance and decreasing whole-body glucose oxidation (Etherton and Bauman, 1998), which leads to a slower glucose clearance rate during the GTT and weaker glucose response to IC of CL cows compared with HT cows. Thus, an increase of GH in CL cows relative to HT cows in early lactation may explain the observed effects in the present experiment. Other endocrine regulators, such as prolactin and glucocorticoids (Bauman, 2000) are affected by heat stress in cattle (Collier et al., 1982a; Wise et al., 1988) and may also be involved in the enhanced homeorhetic regulation in CL cows compared with HT cows and, therefore, cannot be excluded. Indeed, cooling heat-stressed cows during the dry period decreases the circulating prolactin during the prepartum period (do Amaral et al., 2009, 2011; Tao et al., 2011) and increases hepatic prolactin recep- tor gene expression during the dry period and early lactation (do Amaral et al., 2011). Therefore, increased hepatic prolactin signaling in CL cows relative to HT cows during the transition period is suggested to be involved in the enhanced hepatic lipid metabolism to cope with extensive adipose mobilization in early lactation (do Amaral et al., 2009, 2011).

\section{CONCLUSIONS}

Cooling heat-stressed cows during the dry period increased milk production in the subsequent lactation. No differences were observed in blood insulin and metabolite concentrations or effects of insulin on peripheral tissues during late gestation when cows experienced heat stress. But, compared with HT cows, CL cows had higher adipose tissue mobilization, lower basal glucose and insulin concentrations, and reduced insulin responses at peripheral tissues in the first week of lactation. These metabolic adaptations are consistent with the greater milk yield observed in CL cows, and follow the observation of HT cows having reduced mammary capacity for milk synthesis. Therefore, heat stress abatement during the dry period did not affect the metabolism in late gestation but the increased milk yield of CL cows is consistent with known homeorhetic responses in early lactation.

\section{ACKNOWLEDGMENTS}

The authors thank the staff of the Dairy Unit at University of Florida (Gainesville) for animal care and data collection. The appreciation also is extended to J. E. P. Santos (University of Florida, Gainesville) for the critical review and valuable suggestions and D. R. Bray (University of Florida, Gainesville) for the tremendous help with the cooling system setup. This study was funded by US Department of Agriculture-Agriculture and Food Research Initiative (USDA-AFRI) Competitive Grant \#2010-85122-20623 to G. E. Dahl.

\section{REFERENCES}

Adin, G., A. Gelman, R. Solomon, I. Flamenbaum, M. Nikbachat, E. Yosef, A. Zenou, A. Shamay, Y. Feuermann, S. J. Mabjeesh, and J. Miron. 2009. Effects of cooling dry cows under heat load conditions on mammary gland enzymatic activity, intake of food water, and performance during the dry period and after parturition. Livest. Sci. 124:189-195.

Avendaño-Reyes, L., F. D. Alvarez-Valenzuela, A. Correa-Calderón, J. S. Saucedo-Quintero, P. H. Robinson, and J. G. Fadel. 2006. Effect of cooling Holstein cows during the dry period on postpartum performance under heat stress conditions. Livest. Sci. 105:198-206.

Bauman, D. E. 2000. Regulation of nutrient partitioning during lactation: Homeostasis and homeorhesis revisited. Pages 311-328 in Ruminant Physiology: Digestion, Metabolism, Growth and Reproduction. P. B. Cronjé, ed. CABI Publishing, Wallingford, UK. 
Bauman, D. E., and W. B. Currie. 1980. Partitioning of nutrients during pregnancy and lactation: A review of mechanisms involving homeostasis and homeorhesis. J. Dairy Sci. 63:1514-1529.

Baumgard, L. H., J. B. Wheelock, S. R. Sanders, C. E. Moore, H. B. Green, M. R. Waldron, and R. P. Rhoads. 2011. Postabsorptive carbohydrate adaptations to heat stress and monensin supplementation in lactating Holstein cows. J. Dairy Sci. 94:5620-5633.

Bell, A. W. 1995. Regulation of organic nutrient metabolism during transition from late pregnancy to early lactation. J. Anim. Sci. 73:2804-2819.

Bell, A. W., and D. E. Bauman. 1997. Adaptations of glucose metabolism during pregnancy and lactation. J. Mammary Gland Biol. Neoplasia 2:265-278.

Collier, R. J., D. K. Beede, W. W. Thatcher, L. A. Israel, and C. J. Wilcox. 1982a. Influences of environment and its modification on dairy animal health and production. J. Dairy Sci. 65:2213-2227.

Collier, R. J., G. E. Dahl, and M. J. VanBaale. 2006. Major advances associated with environmental effects on dairy cattle. J. Dairy Sci. 89:1244-1253

Collier, R. J., S. G. Doelger, H. H. Head, W. W. Thatcher, and C. J Wilcox. 1982b. Effects of heat stress during pregnancy on maternal hormone concentrations, calf birth weight and postpartum milk yield of Holstein cows. J. Anim. Sci. 54:309-319.

Dikmen, S., E. Alava, E. Pontes, J. M. Fear, B. Y. Dikmen, T. A. Olson, and P. J. Hansen. 2008. Differences in thermoregulatory ability between slick-haired and wild-type lactating Holstein cows in response to acute heat stress. J. Dairy Sci. 91:3395-3402.

do Amaral, B. C., E. E. Connor, S. Tao, M. J. Hayen, J. W. Bubolz, and G. E. Dahl. 2009. Heat-stress abatement during the dry period: Does cooling improve transition into lactation? J. Dairy Sci. 92:5988-5999.

do Amaral, B. C., E. E. Connor, S. Tao, M. J. Hayen, J. W. Bubolz and G. E. Dahl. 2011. Heat stress abatement during the dry period influences metabolic gene expression and improves immune status in the transition period of dairy cows. J. Dairy Sci. 94:86-96.

Drackley, J. K., T. R. Overton, and G. N. Douglas. 2001. Adaptations of glucose and long-chain fatty acid metabolism in liver of dairy cows during the periparturient period. J. Dairy Sci. 84(E. Suppl.):E100-E112.

Etherton, T. D., and D. E. Bauman. 1998. Biology of somatotropin in growth and lactation of domestic animals. Physiol. Rev. 78:745761

Hayirli, A. 2006. The role of exogenous insulin in the complex of hepatic lipidosis and ketosis associated with insulin resistance phenomenon in postpartum dairy cattle. Vet. Res. Commun. 30:749-774.

Hayirli, A., D. R. Bremmer, S. J. Bertics, M. T. Socha, and R. R. Grummer. 2001. Effect of chromium supplementation on production and metabolic parameters in periparturient dairy cows. J. Dairy Sci. 84:1218-1230.

Holtenius, K., S. Agenäs, C. Delavaud, and Y. Chilliard. 2003. Effects of feeding intensity during the dry period. 2. Metabolic and hormonal response. J. Dairy Sci. 86:883-891.

Kahn, C. R. 1978. Insulin resistance, insulin insensitivity, and insulin unresponsiveness: A necessary distinction. Metabolism 27:18931902 .
Kim, K. H., D.-H. Kim, Y.-K. OH, S.-S. Lee, H.-J. Lee, D.-W. Kim Y.-J. Seol, and N. Kimura. 2010. Productivity and energy partition of late lactation dairy cows during heat exposure. Anim. Sci. J. $81: 58-62$.

Malven, P. V., H. H. Head, R. J. Collier, and F. C. Buonomo. 1987. Periparturient changes in secretion and mammary uptake of insulin and in concentrations of insulin and insulin-like growth factors in milk of dairy cows. J. Dairy Sci. 70:2254-2265.

NRC. 2001. Nutrient Requirements of Dairy Cattle. 7th rev. ed. Natl. Acad. Press, Washington, DC.

Pires, J. A. A., J. B. Pescara, A. E. Brickner, N. Silva del Rio, A. P. Cunha, and R. R. Grummer. 2008. Effects of abomasal infusion of linseed oil on responses to glucose and insulin in Holstein cows. J. Dairy Sci. 91:1378-1390.

Rhoads, M. L., J. W. Kim, R. J. Collier, B. A. Crooker, Y. R. Boisclair, L. H. Baumgard, and R. P. Rhoads. 2010. Effects of heat stress and nutrition on lactating Holstein cows: II. Aspects of hepatic growth hormone responsiveness. J. Dairy Sci. 93:170-179.

Rhoads, M. L., R. P. Rhoads, M. J. VanBaale, R. J. Collier, S. R. Sanders, W. J. Weber, B. A. Crooker, and L. H. Baumgard. 2009. Effects of heat stress and plane of nutrition on lactating Holstein cows: I. Production, metabolism, and aspects of circulating somatotropin. J. Dairy Sci. 92:1986-1997.

Sechen, S. J., F. R. Dunshea, and D. E. Bauman. 1990. Somatotropin in lactating cows: Effect on response to epinephrine and insulin. Am. J. Physiol. 258:E582-E588

Tao, S., J. W. Bubolz, B. C. do Amaral, I. M. Thompson, M. J. Hayen, S. E. Johnson, and G. E. Dahl. 2011. Effect of heat stress during the dry period on mammary gland development. J. Dairy Sci. 94:5976-5986.

Tarazón-Herrera, M., J. T. Huber, J. Santos, H. Mena, L. Nusso, and C. Nussio. 1999. Effects of bovine somatotropin and evaporative cooling plus shade on lactation performance of cows during summer heat stress. J. Dairy Sci. 82:2352-2357.

Urdaz, J. H., M. W. Overton, D. A. Moore, and J. E. P. Santos 2006. Technical note: Effects of adding shade and fans to a feedbunk sprinkler system for preparturient cows on health and performance. J. Dairy Sci. 89:2000-2006.

Vernon, R. G., and G. M. Pond. 1997. Adaptations of maternal adipose tissue to lactation. J. Mammary Gland Biol. Neoplasia $2: 231-241$.

Wheelock, J. B., R. P. Rhoads, M. J. VanBaale, S. R. Sanders, and L. H. Baumgard. 2010. Effects of heat stress on energetic metabolism in lactating Holstein cows. J. Dairy Sci. 93:644-655.

Wise, M. E., D. V. Armstrong, J. T. Huber, R. Hunter, and F. Wiersma. 1988. Hormonal alterations in the lactating dairy cow in response to thermal stress. J. Dairy Sci. 71:2480-2485.

Wolfenson, D., I. Flamenbaum, and A. Berman. 1988. Dry period heat stress relief effects on prepartum progesterone, calf birth weight, and milk production. J. Dairy Sci. 71:809-818. 